\title{
Changes in numbers and distribution of wintering waterbirds at the south coast of Scania, Sweden, during 55 winters, 1964-2018
}

\section{Förändringar i antal och lokal utbredning hos övervintrande sjöfåglar vid den skånska sydkusten under 55 vintrar, 1964-2018}

Leif Nilsson

Department of Biology, Lund University, Ecology Building, 22362 Lund, Sweden | leif.nilsson@biol.lu.se

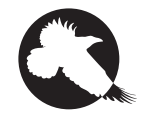

THE SOUTH COAST of Scania, southernmost Sweden, has long been an important wintering and staging area for waterbirds. A large part of the coast was surveyed annually as a part of the international midwinter counts for 55 years (1964-2018). The total number of wintering waterbirds showed an increasing trend but there was much variation between years. Common Goldeneye Bucephala clangula, followed by Mallard Anas platyrhynchos, Tufted Duck Aythya fuligula and-during the early years-Long-tailed Duck Clangula hyemalis, dominated the community. Great Cormorant Phalacrocorax carbo, Mallard, Common Goldeneye and Eurasian Coot Fulica atra increased in numbers, reflecting the national and international trends related to milder winters and a northward shift of the winter distribution. Eurasian Wigeon Mareca penelope and Great Crested Grebe Podiceps cristatus established wintering traditions in the area during the study period. Tufted Duck and Common Merganser Mergus merganser decreased locally due to a northward shift of the wintering distribution northwards within the country. The Long-tailed Duck was an important winter guest in the first years but was only seen in very small numbers in later years, reflecting the general and large-scale decrease of the Baltic wintering population.

Keywords: diving duck | Mallard| Long-tailed Duck | Anatidae | wintering ecology 


\section{Introduction}

The south coast of Scania, the southernmost province of Sweden, has since long been known as an important wintering area for a number of waterbird species, being an area offering at least some open water even during the coldest winters (cf. e.g. Nilsson 1972, Nilsson 2008, Nilsson \& Haas 2016).

During the years 1964-1969, intensive studies of the non-breeding ecology of diving ducks was undertaken in SW Scania with the main part of the south coast of the province and areas in the Öresund as main study areas (cf. Nilsson 1970a, 197ob, 1970c, 1972, 1975). The studies included local distribution and habitat selection, seasonal appearance, feeding ecology, and the exploitation of feeding areas. After this period of intensive work, the wintering waterbirds in the old study area were surveyed in midwinter each year as part of the international midwinter counts organized by Wetlands International (Nilsson 2008, Nilsson \& Haas 2016).

In the present paper I will analyze this continuous series of midwinter counts of waterfowl to follow the development of the local wintering populations of the different species 1964-2018 against the background of the national (and international) pattern. I will establish, for the different species, whether there have been any changes in numbers and local distribution over the years.

\section{Study area}

For the International Waterbird Counts (IWC), the entire Swedish coast was divided into smaller counting units based on suitable landmarks and habitat differences (Nilsson 2008, Nilsson \& Haas 2016). The study area on the south coast of Scania between Kämpinge and Ystad comprises 20 counting sectors from the IWC, of which one (the harbor of Trelleborg) is omitted from this analysis, because access has been restricted during the last decades. In the present study, I have grouped these counting sectors into five subareas of the main study area (Figure 1).

Overall, the south coastline consists of moraine shores with plenty of rocks and boulders in the water, interspersed by some sandy beaches. There are also many rocks and boulders in the water some distance from sandy beaches. In general, the shore profile was steeper in the eastern parts in subareas 1 and 2 (Figure 1) between the sandy beaches, whereas the profile was flatter in subareas $3-5$, with some areas with boulder beaches in subareas 2 and 3. Figure 2 shows examples of moraine shorelines.

There are two larger harbors in the study area, the ferry harbors of Trelleborg (the border between subarea 4 and 5; Figure 1) and Ystad (in the eastern part of subarea 1; Figure 1). The Trelleborg harbor is not included, as it could not be visited on a regular basis,

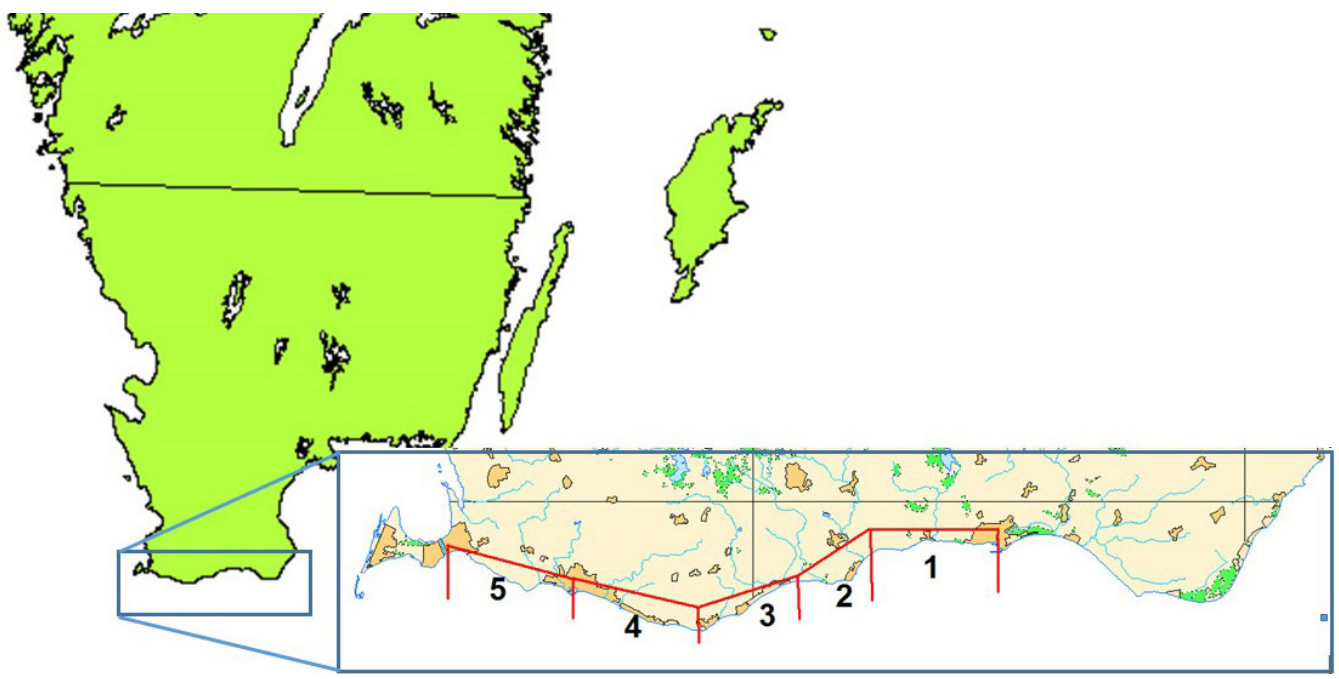

FIGURE 1. Map of southern Sweden with details of the south coast study area and its division into subareas for the analyses.

- Karta över södra Sverige med detaljer över undersökningsområdet på sydkusten med den indelning i delområden som används vid analyserna. 


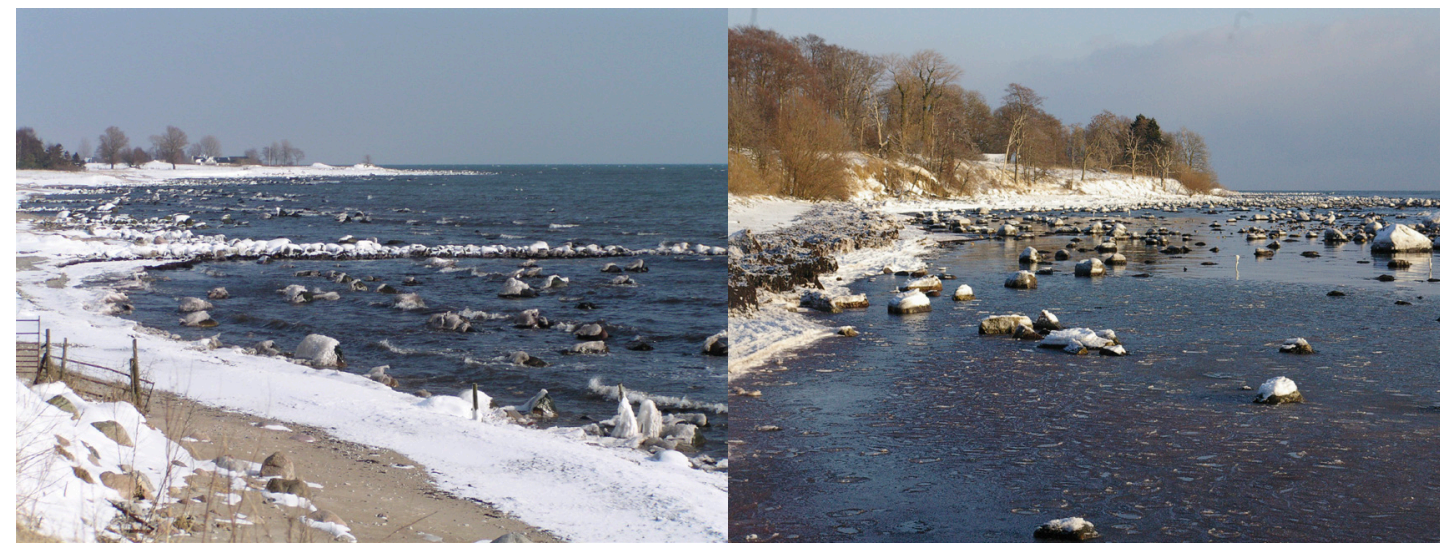

FIGURE 2. Two examples of steep moraine coast in area 2 (Abbekås-Hörte) on the south coast of Scania. Photo: Leif Nilsson. - Två exempel på moränkust i delområde 2 (Abbekås-Hörte) på den skånska sydkusten. Foto: Leif Nilsson.

whereas the Ystad harbor is included in the study. In addition to these two large harbors, there are four smaller fishing harbors in the study area. Some stretches along the coast are inhabited (especially the eastern part of Trelleborg (subarea 4; Figure 1) but there was always an open area close to the shoreline.

The vegetation and fauna of the shallow areas of the south coast study area were described by Nilsson (1970c, 1972) based on dredging in the areas out to a depth of about $6 \mathrm{~m}$. The algae vegetation of the stony moraine areas is rich and dominated by Fucus vesiculosus close to the shore and Fucus serratus in deeper water. Various red algae were common on the rocks and gravel as was Enteromorpha sp.

Blue mussels Mytilus edulis dominated all areas except for the sandy beaches. In deeper water, Mytilus was found on the moraine patches. The boulders formed an important substrate for small mussels, as did some of the lager algae. Large numbers of different crustaceans, especially Gammarus sp. and Idothea sp. occur among the algae and rocks and are an important food source for diving ducks. For further information on the habitats and food resources of the south coast of Scania, see Nilsson (1970c, 1972).

\section{Material and methods}

For the midwinter counts, the entire Swedish coastline was divided into smaller counting sectors which could be covered from suitable observation points along the shore by binoculars and telescope. Clearly defined items in the terrain such as small peninsulas, fishing harbors etc. were chosen as borders between the counting sectors. In the present analysis, the twenty counting sectors in the study area were grouped into five larger subareas (Figure 1) based on habitat characteristics.

As the counts on the south coast of Scania were part of the International Waterfowl Counts in Sweden, they were undertaken as close to the 15 January as possible. The counts started in the morning and continued while there was daylight. Depending on weather conditions, the counts were carried out in one or two days by one observer. The majority of the counts were made by the author. Counts were only made in good weather conditions; especially wind conditions were important, and no counts were made in strong winds.

During the first years of the counts, only anatids were counted. The Eurasian Coot Fulica atra was included from 1968 and starting in 1971 loons, grebes, herons, and cormorants were also included. As the counts discussed here were all undertaken from the shoreline, it was not possible to cover the offshore areas fully. Due to the generally steep shore profile, and thus the elevated position of the observer, all anatid species except the Long-tailed Duck Clangula hyemalis and the scoters Melanitta spp. are considered to be fully covered. Boat surveys (Nilsson 1972) and aerial surveys (Nilsson 2016) have shown appreciable numbers of Long-tailed Ducks and smaller numbers of Velvet Scoters Melanitta fusca and Common Scoters Melanitta nigra wintering 
in the offshore waters south of the coast of Scania, the scoters mostly in areas to the west of the study area (Green \& Nilsson 2015).

In all 55 years discussed in the paper, total counts from the shore were made in all counting sectors in each year, thus the numbers presented are total counts for the entire study area if not specified to subareas. Trends over the series of total numbers were tested by linear regression.

\section{Results}

The total number of waterbirds wintering in the study area varied much over the years, between about 2,000 to almost 18,000 individuals, with an overall significantly increasing trend (Figure 3 ). However, if the Mallard Anas platyrhynchos is excluded the trend is no longer significant. Few species dominated the waterbird community along the south coast (Figure 4), but several other species were found in smaller numbers (Table 1). The most common species over the years was the Common Goldeneye Bucephala clangula with $35 \%$ of the total number of individuals observed over the 55 years of midwinter counts in the area. The second most common species was the Mallard, followed by the Tufted Duck Aythya fuligula and the Long-tailed Duck. The latter species also occurs far out at sea, where it cannot be detected from land.

Ten species showed significant trends over the entire period, seven of which were increasing and three were decreasing (Figure 5, Table 1). The wintering numbers and trends of the main species are discussed separately below and illustrated in Figure 5, whereas the local distributions of these species are shown for four time periods in Figure 6.

\section{MUTE SWAN CYGNUS OLOR}

The number of wintering Mute Swans has shown a marked variation during the study period with a maximum midwinter total of 1,024 in 1985 , whereas only very few swans were counted in some years. The majority of the Mute Swans were found in the western

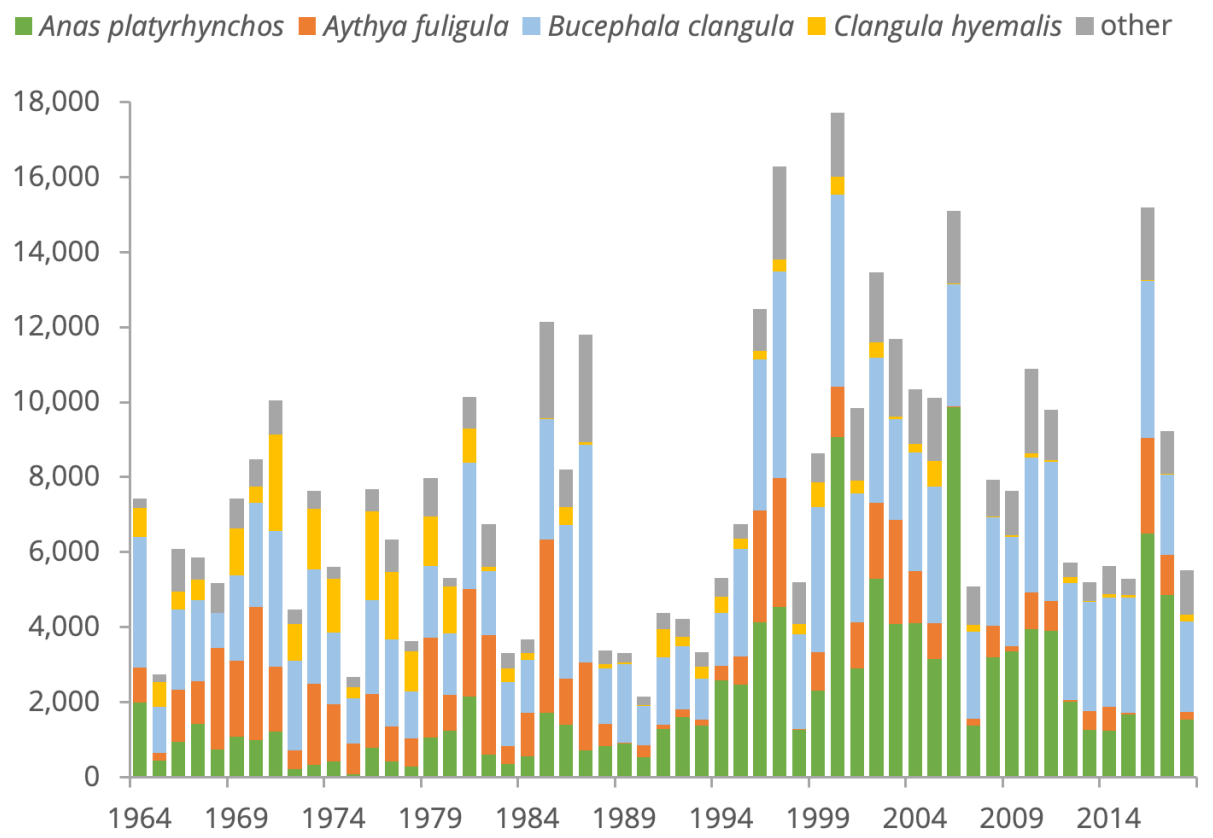

FIGURE 3. Total number of wintering waterbirds counted in the study area on the Scanian south coast 1964-2018. The increase for the total number of wintering waterfowl over the 55 years was significant (linear regression $r=0.31, p=0.02$ ) and driven by the increase of Mallards Anas platyrhynchos.

- Totalantalet övervintrande sjöfåglar vid den skånska sydkusten 1964-2018. Ökningen för totalantalet övervintrare under de 55 åren var signifikant (linjär regression $r=0,31, p=0.02$ ) och drevs av den ökade mängden gräsänder Anas platyrhynchos. 


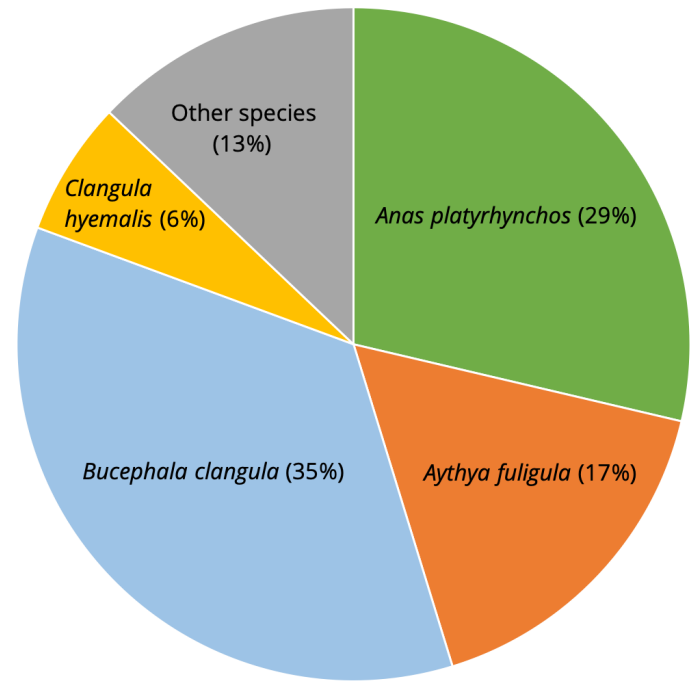

FIGURE 4. Species composition (percent) for the wintering waterbirds along the south coast of Scania 1964-2018 based on all annual midwinter counts.

- Artsammansättningen (i procent) för de övervintrande sjöfåglarna på sydkusten av Skåne 1964-2018 baserad på samtliga årliga midvinterinventeringar

part of the study area (Figure 6), the only part of the south coast with rich underwater meadows of eelgrass Zostera sp.

\section{EURASIAN WIGEON MARECA PENELOPE}

Before 1990, hardly any Eurasian Wigeons stayed in Sweden over the winter, only a few single individuals (Nilsson \& Haas 2016) being reported. During the 1990 s, a wintering tradition was established in the southernmost part of the country with up to several thousand Eurasian Wigeons wintering especially in the southern part of the Öresund, an area long known as a major staging area for the Eurasian Wigeon during the migration periods.

January 1997 was the first time larger numbers were counted on the south coast, with close to one thousand, compared to just single individuals in some of the previous years. The Eurasian Wigeons were found in the westernmost subarea of the south coast, close to the area with the main concentration in the Öresund region. The Eurasian Wigeons, like the Mallards, mainly used the coastal area as a daytime roost, making feeding flights in the evening to the agricultural areas inland, where they mainly feed on rape Brassica napus (pers. obs.).

\section{MALLARD ANAS PLATYRHYNCHOS}

Overall, $29 \%$ of all counted waterfowl in the area were Mallards. Like most other species the number of Mallards counted varied much between different years, but the species showed a marked increase over the years being much more common during the second half of the study period than during the first. The peak count in later years was close to 10,000 , whereas annual totals were lower than 2,00o in the first part of the study period. The overall trend was highly significant (Table 1). The local distribution of the species was similar over the study period (Figure 6). About $60 \%$ of the Mallards were counted in the two easterly subareas (Figure 1) where they were mostly found resting among the stones on the moraine coast. The Mallards mainly used the coast as a daytime roosting site, making feeding flights into the agricultural areas inland.

\section{TUFTED DUCK AYTHYA FULIGULA}

The counts of Tufted Ducks showed much variation between the years (Figure 5). Numbers were highest during the first half of the study period, when the species in some years was the most common species in the study area with a peak count of more than 4,600. The overall trend was significantly decreasing (Table 1). Overall, the Tufted Duck was the third most common duck species in the area calculated over the entire period ( $17 \%$ of all counted ducks). The majority of the Tufted Ducks were found in the eastern subarea (Figure 6), mostly in the harbor of Ystad. Smaller flocks were also found in the other areas, predominantly close to smaller harbors. The Tufted Ducks are generally feeding at night and roosted over the day in protected areas such as harbors. Over the study period, the Tufted Ducks became more and more concentrated to the Ystad harbor, as numbers using the south coast in winter decreased (Figure 6).

\section{GREATER SCAUP AYTHYA MARILA \& COMMON POCHARD AYTHYA FERINA}

Both these species were counted in relatively small numbers in most years, but sometimes higher counts were noted with a maximum of 110 individuals for the Greater Scaup and about 70 for the Common Pochard. Greater Scaups and Common Pochards were normally found in small numbers in the larger flocks of Tufted Ducks. 
TABLE 1. Max counts, mean counts per year, and trends for the different species counted along the south coast of Scania, Sweden, at the midwinter counts in 1964-2018. For species with max count $>100$, the trends were tested by linear regression and are presented with the regression coefficient, representing the average change in numbers per year, and significance level: $p<0.001\left(^{* * *}\right), p<0.01(* *), p<0.05(*)$, or not significant (NS).

- Högsta totalsumma, medeltal och trender för de olika arterna vid midvinterinventeringar efter den skånska sydkusten 1964-2018. För arter med högsta totalsumma $>100$ prövades trender med linjär regression och presenteras med regressionskoefficienten, vilken motsvarar den genomsnittliga förändringen i antal per år, samt signifikansnivå: $p<0.001\left(^{* * *}\right), p<0.01\left(^{* *}\right), p<0.05\left(^{*}\right)$ eller icke signifikant (NS).

\begin{tabular}{|c|c|c|c|c|c|c|}
\hline \multicolumn{3}{|c|}{ Species Art } & \multirow{2}{*}{$\begin{array}{l}\text { Max count } \\
\text { Maxantal }\end{array}$} & \multirow{2}{*}{$\begin{array}{l}\text { Mean }(\text { if }>1) \\
\text { Medeltal }(o m>1)\end{array}$} & \multirow{2}{*}{\multicolumn{2}{|c|}{$\begin{array}{l}\text { Trend } \\
\text { Trend }\end{array}$}} \\
\hline $\begin{array}{l}\text { English name } \\
\text { Engelskt namn }\end{array}$ & Swedish name & Scientfic name & & & & \\
\hline Mute Swan & knölsvan & Cygnus olor & 1,024 & 134 & 2.0 & NS \\
\hline Whooper Swan & sångsvan & Cygnus cygnus & 65 & 8 & & \\
\hline Common Shelduck & gravand & Tadorna tadorna & 25 & 2 & & \\
\hline Northern Shoveler & skedand & Spatula clypeata & 1 & & & \\
\hline Gadwall & snatterand & Mareca strepera & 1 & & & \\
\hline Eurasian Wigeon & bläsand & Mareca penelope & 1,225 & 102 & 7.1 & \\
\hline Mallard & gräsand & Anas platyrhynchos & 9,867 & 2,152 & 71.1 & $\star \star *$ \\
\hline Northern Pintail & stjärtand & Anas acuta & 1 & & & \\
\hline Eurasian Teal & kricka & Anas crecca & 95 & 7 & & \\
\hline Common Pochard & brunand & Aythya ferina & 70 & 9 & & \\
\hline Tufted Duck & vigg & Aythya fuligula & 4,628 & 1,255 & -18.6 & * \\
\hline Greater Scaup & bergand & Aythya marila & 76 & 12 & & \\
\hline Steller's Eider & alförrädare & Polysticta stelleri & 2 & & & \\
\hline Common Eider & ejder & Somateria mollissima & 231 & 36 & -1.3 & $\star \star \star$ \\
\hline Velvet Scoter & svärta & Melanitta fusca & 8 & & & \\
\hline Common Scoter & sjöorre & Melanitta nigra & 7 & & & \\
\hline Long-tailed Duck & alfågel & Clangula hyemalis & 2,560 & 506 & -21 & $\star * *$ \\
\hline Common Goldeneye & knipa & Bucephala clangula & 5,802 & 2,705 & 24.2 & $\star *$ \\
\hline Smew & salskrake & Mergellus albellus & 20 & 2 & & \\
\hline Common Merganser & storskrake & Mergus merganser & 1,514 & 201 & -4.6 & NS \\
\hline Red-breasted Merganser & småskrake & Mergus serrator & 659 & 177 & 2.1 & NS \\
\hline Red-throated Loon & smålom & Gavia stellata & 3 & & & \\
\hline Black-throated Loon & storlom & Gavia arctica & 6 & & & \\
\hline Little Grebe & smådopping & Tachybaptus ruficollis & 2 & & & \\
\hline Red-necked Grebe & gråhakedopping & Podiceps grisegena & 2 & & & \\
\hline Great Crested Grebe & skäggdopping & Podiceps cristatus & 391 & 26 & 1.2 & \\
\hline Horned Grebe & svarthakedopping & Podiceps auritus & 3 & & & \\
\hline Grey Heron & gråhäger & Ardea cinerea & 9 & & & \\
\hline Great Cormorant & storskarv & Phalacrocorax carbo & 242 & 51 & 3.0 & $\star \star *$ \\
\hline Eurasian Coot & sothöna & Fulica atra & 1,263 & 226 & 6.3 & $\star *$ \\
\hline
\end{tabular}



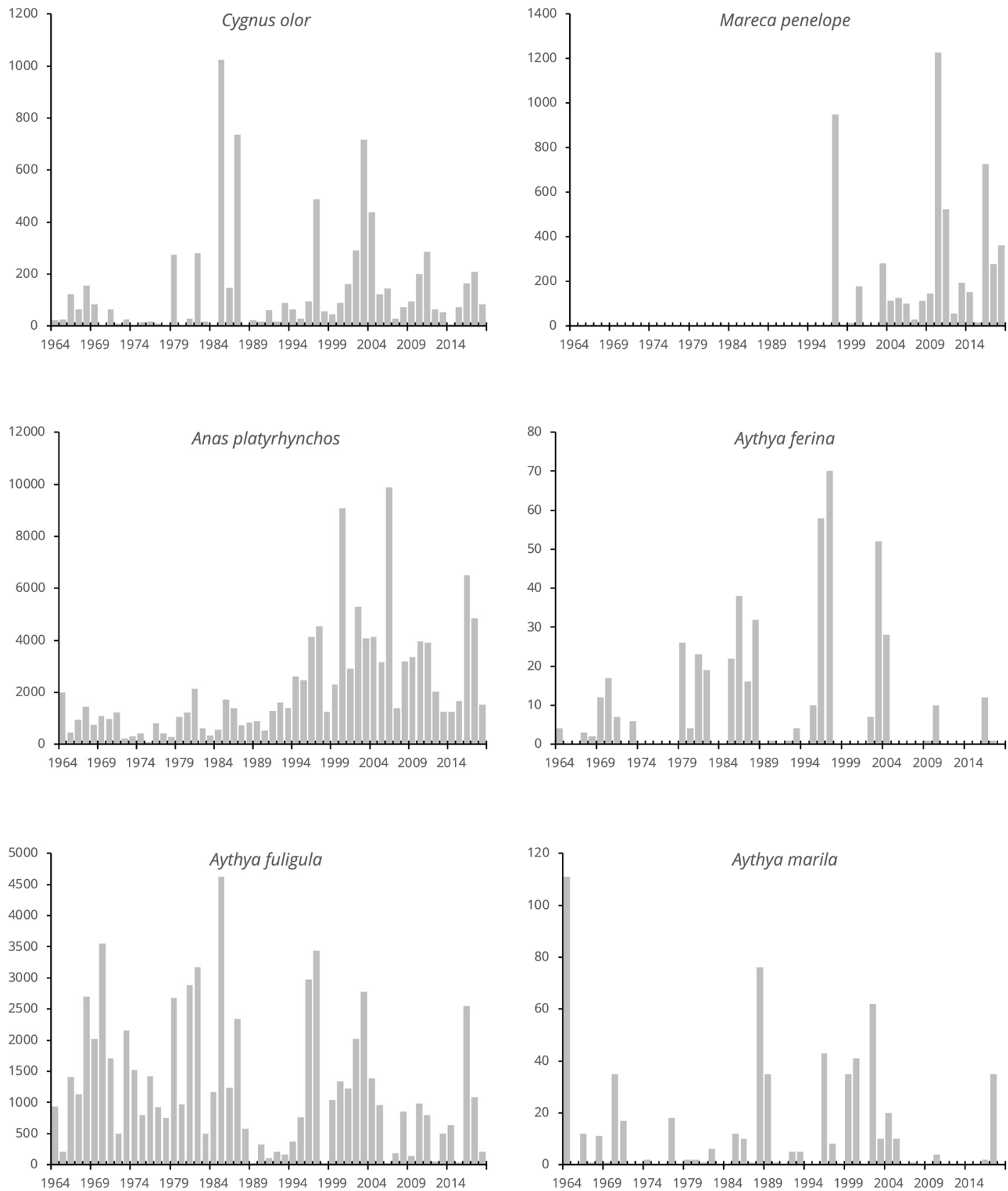

FIGURE 5. Annual totals for the more common species at the annual midwinter counts in the study area on the south coast of Scania in 1964-2018. The panels are labeled with scientific species names, for common names, see Table 1

- Årliga totalsummor för de vanligaste arterna vid de årliga midvinterinventeringarna i undersökningsområdet längs den skånska sydkusten 1964-2018. De individuella figurerna är märkta med vetenskapliga namn, se tabell 1 för svenska namn. 

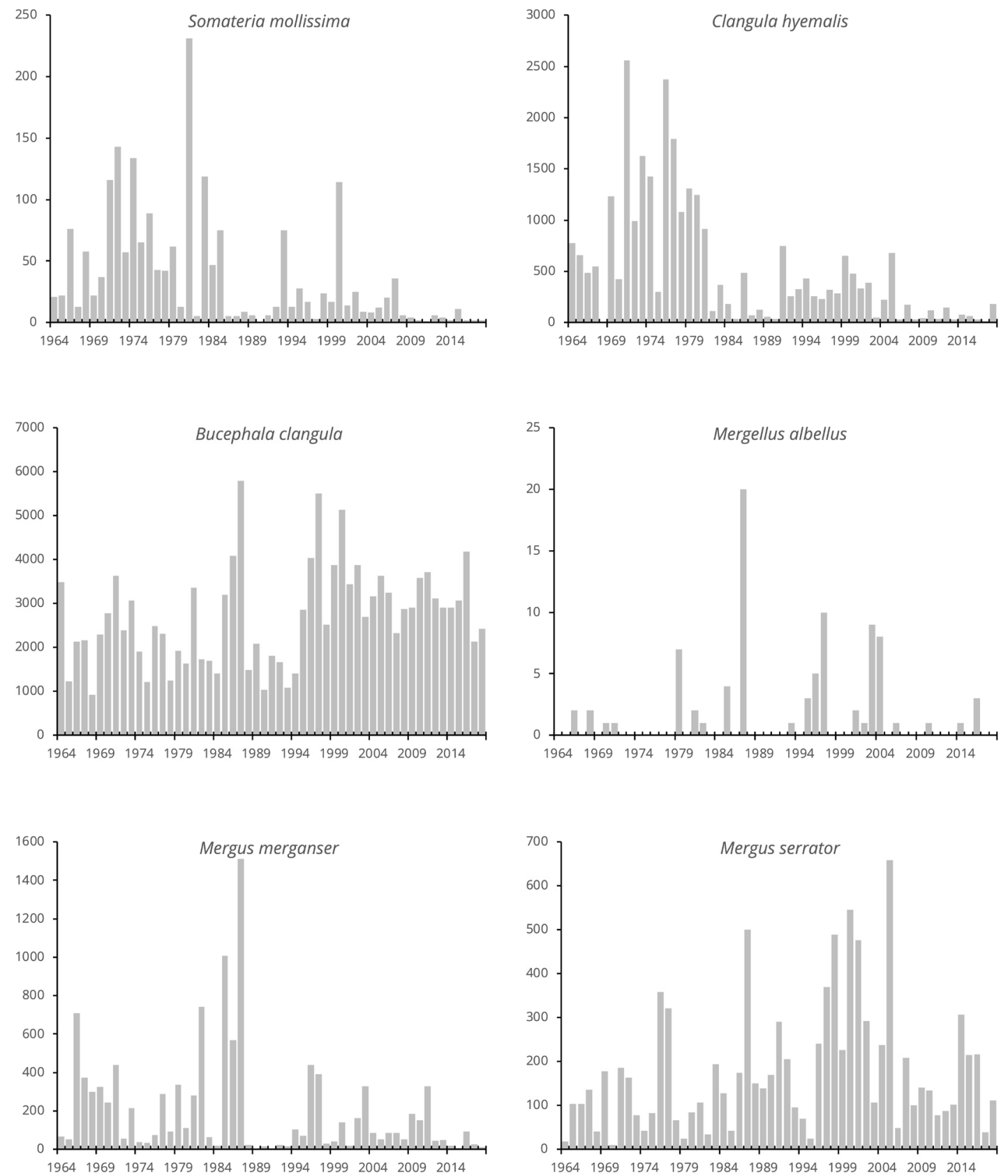

FIGURE 5 continued | Figur 5 fortsatt. 

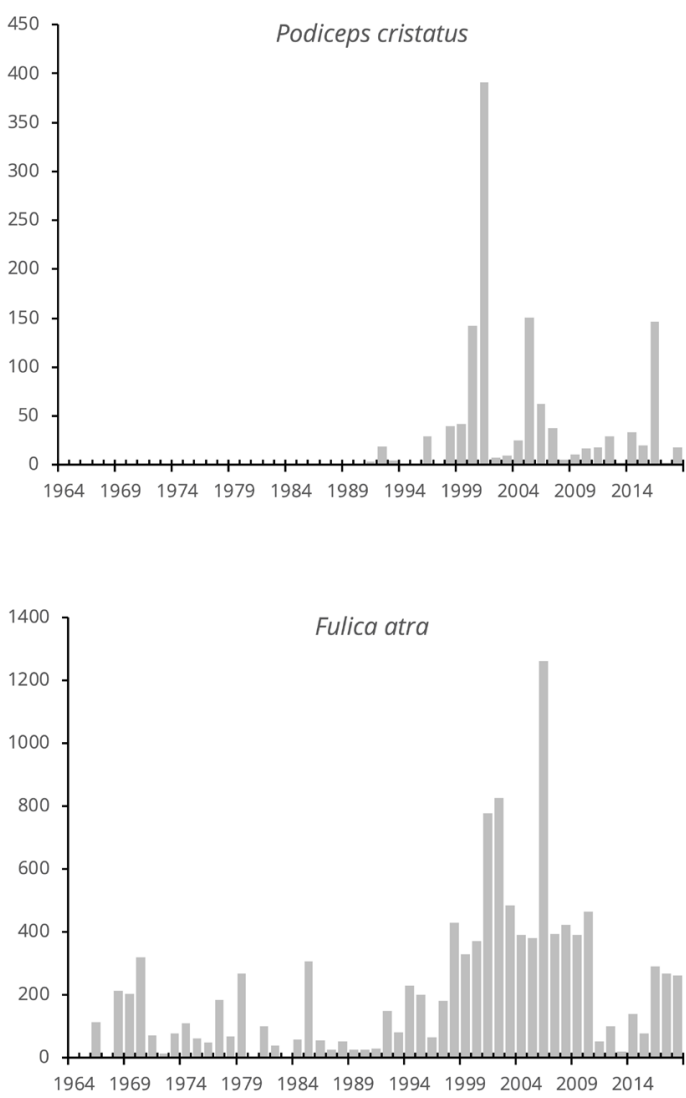

FIGURE 5 continued | Figur 5 fortsatt.

\section{COMMON EIDER SOMATERIA MOLLISSIMA}

The Common Eider was found in relatively small numbers wintering on the south coast of Scania, the highest count being 230 in 1981. The species showed a marked and significantly decreasing trend over the years, and only single wintering Common Eiders were found in the area during the last ten years. In the early years of the study, Common Eiders were found in most parts of the study area, but over the years they became more concentrated to the western subareas (Figure 6).

\section{LONG-TAILED DUCK CLANGULA HYEMALIS}

When the counts started, the Long-tailed Duck was one of the most common species of ducks counted on the south coast together with Mallard, Tufted Duck and Common Goldeneye, with a maximum count from the shore of more than 2,500 (January 1971). At the same time, much higher numbers wintered further out at

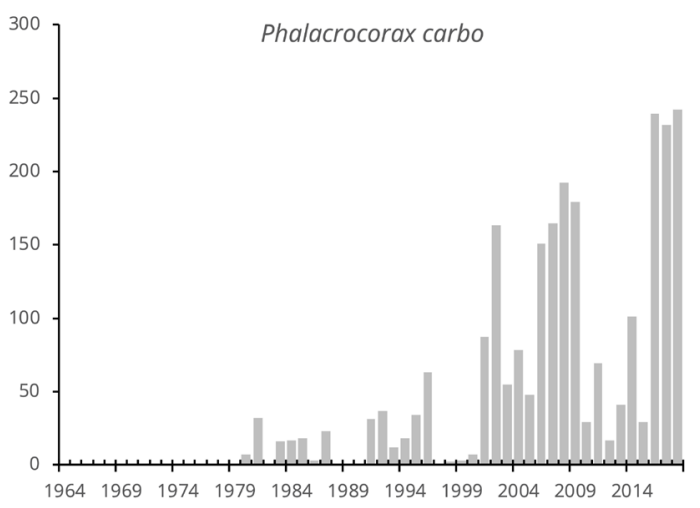

sea (cf. Nilsson 1972). High numbers in the inshore areas were still seen until 1980, after which numbers decreased markedly, and from 2010 more than 100 individuals were only reported in two winters. The trend was strongly decreasing (and highly significant). Aerial surveys in the offshore areas during 2009 and 2016 showed much lower numbers of Long-tailed Ducks than the early boat surveys in the 1960 s and 1970 s (Nilsson 1980, 2016).

Over the years, about $80 \%$ of the Long-tailed Ducks were counted in the two eastern subareas, i.e. between Hörte and Ystad. This could, however, partly be an effect of the shore topography with extensive moraine bottoms with rich mussel beds close to the shore in this part of the south coast. In the western areas, most Longtailed Ducks stayed further offshore (Nilsson 1972) and could not be counted from the shore. There was also a shift over the years in occurrence between the two eastern subareas, with Long-tailed Ducks becoming more concentrated to subarea 2 (Hörte-Abbekås) with rich moraine bottoms all the way to the shore.

\section{COMMON GOLDENEYE BUCEPHALA CLANGULA}

Over the entire study period of midwinter counts, the Common Goldeneye was the most common duck with $35 \%$ of all counted (Figure 4 ). The highest count was noted during the cold and icy winter of 1987 , when more than 5,800 were found in the area compared to a mean total of 2,700 over the entire series. The Common Goldeneyes showed a significantly increasing trend over the entire study period but there was a marked variation between years.

There were some changes in the local distribution of the species over time. During the first half of the study 

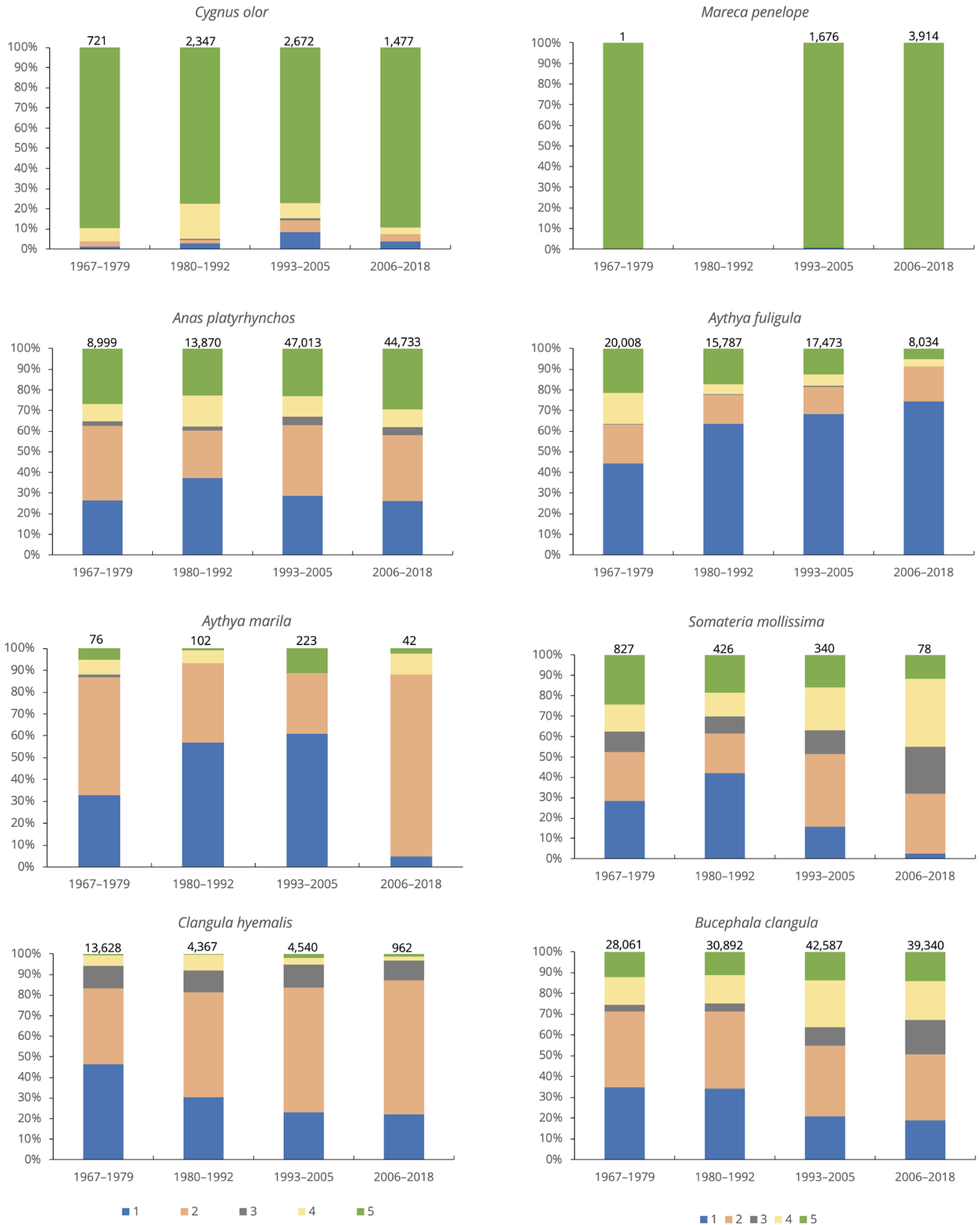

FIGURE 6. Distribution (percent) of the most common species of waterbirds over five different subareas (see Figure 1) in the study area on the south coast of Scania during four time periods. Totals of all annual counts of a species in the different time periods shown above the bars. The panels are labeled with scientific species names, for common names, see Table 1.

- Fördelning (i procent) av de vanligaste sjöfåglarna på fem olika delområden (se figur 1) efter den skånska sydkusten under fyra olika tidsperioder. Totalsumman för respektive art inom varje tidsperiod visas ovanför staplarna. De individuella figurerna är märkta med vetenskapliga namn, se tabell 1 för svenska namn. 


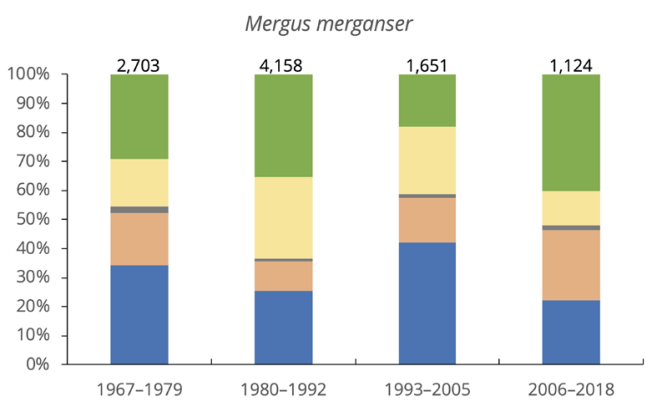

Podiceps cristatus

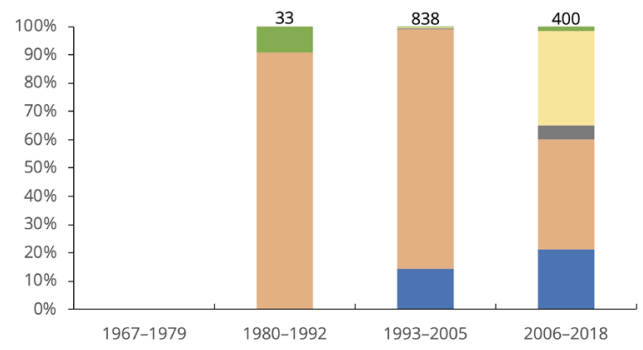

Fulica atra

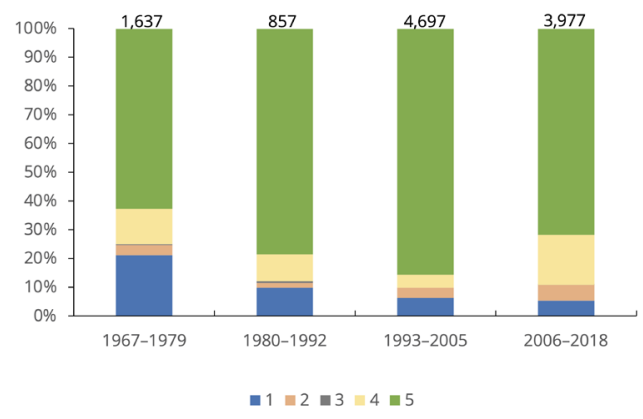

period about $70 \%$ of the Common Goldeneyes were found in the two easternmost subareas compared to the latter part of the study period, when about $50 \%$ were counted there. The main increase in wintering numbers occurred in the western part of the study area.

\section{SMEW MERGELLUS ALBELLUS}

The Smew is mainly an inland species in Scania but small numbers were found at the coast in some years (Figure 5), the maximum count for the area being 20 individuals recorded in the very cold winter of 1987.

\section{COMMON MERGANSER MERGUS MERGANSER}

The Common Merganser was a regular wintering vis-
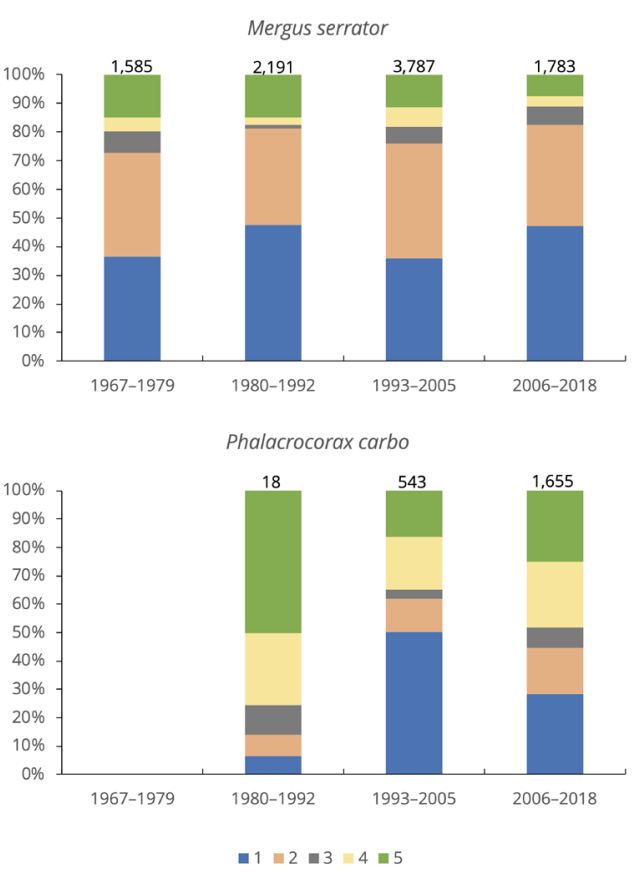

FIGURE 6 continued | Figur 6 fortsatt.

itor to the south coast in quite varying numbers, the maximum count being 1,514 in the cold and icy winter of 1987. Over the years, there was a decreasing trend in the number of wintering Common Mergansers in the area, probably related to warmer winters with less ice in the preferred inland lakes and streams. There were no marked changes in the local distribution over the study period.

\section{RED-BREASTED MERGANSER MERGUS SERRATOR}

The Red-breasted Merganser was also a regularly wintering species along the south coast. Numbers varied much between years without any clear trend, the highest total for the south coast being 659 (2005). The species can stay quite far out at sea (Nilsson 1972) and part of the variation between counts may be due to the weather conditions, because individuals far out at sea are difficult to observe in windy weather. Between $70 \%$ and $80 \%$ of the Red-breasted Mergansers were found in the two easterly subareas, the local distribution being similar over the years (Figure 6). 


\section{GREAT CRESTED GREBE PODICEPS CRISTATUS}

Grebes and cormorants were first included in the International Waterfowl Counts in Sweden in the winter of 1971, but grebes were not regularly seen before 1991, before which single Great Crested Grebes were only seen twice. In later years, grebes were seen in most years. Normally, numbers have been quite small, but in three winters, more than 100 grebes were counted with a highest total of 391 in January 2001. The majority of the Great Crested Grebes were found in subarea 2, more specifically in a relatively restricted area east of Abbekås (Figure 6).

\section{GREAT CORMORANT PHALACROCORAX CARBO}

The Great Cormorant was first included in the winter of 1971, but the first Great Cormorants on the south coast were not seen until 1980, when 7 individuals were counted. The wintering numbers showed a marked increase although with some annual variation, and the highest count for the series 242 Great Cormorants in the last year of the study period, 2018. In the three time periods with wintering Great Cormorants, there has been some variation in the local distribution (Figure 6), and generally the largest numbers have been counted at the different harbors in the area.

\section{EURASIAN COOT FULICA ATRA}

The Eurasian Coot has been a regular winter visitor to the south coast, but numbers have varied over the years. From 1994 onwards, numbers have been generally higher than in the first years of the study and the overall trend was significantly increasing even if there was much variation between years. Over time, the majority of all Eurasian Coots was found in the westernmost subarea (Figure 6). As for the Mute Swan, this distribution is related to the occurrence of eelgrass meadows there.

\section{Discussion}

As shown by Nilsson (1972), the Swedish south coast offers excellent feeding conditions for diving ducks, especially those feeding on bivalves, such as Common Goldeneyes, Tufted Ducks and Long-tailed Ducks. On the other hand, there are no larger suitable feeding areas for dabbling ducks along most parts of the south coast, as the shore has a steep profile in most parts.
Large parts of the south coast are however used as an important roosting area for large flocks of Mallards, which make regular feeding flights in the evening to the neighboring agricultural areas. In general, the waterbird community of the study area was dominated by a few species: Common Goldeneye, Tufted Duck and Mallard.

The counts showed marked between-year variation in the wintering numbers of the different species. Of the more common species, four showed significantly increasing local long-term trends: Great Cormorant, Mallard, Common Goldeneye and Eurasian Coot. On the other hand, four species showed significantly decreasing long-term trends locally: Tufted Duck, Long-tailed Duck, Common Eider and Common Merganser.

All four species increasing in the south coast area also showed significant long-term increasing trends in the national midwinter trends (Nilsson \& Haas 2016, Haas \& Nilsson 2018). Of these species, the Great Cormorant was not a winter visitor to the area when the counts started and was not seen in the area before 1980. Two other species that also established the south coast as a regular wintering site during the study period were the Eurasian Wigeon and the Great Crested Grebe. Nationally, the Eurasian Wigeon started wintering in south Sweden from 1990, the main area being the southern part of the Öresund (Nilsson \& Haas 2016). Smaller numbers of grebes have been seen at the national midwinter counts since the start, but in later years, wintering flocks appeared in the Baltic Sea and especially in the Öresund region.

The increasing trends for the Mallard, Common Goldeneye and Eurasian Coot are a general reflection of the effect of milder winters leading to a short-stopping for these species and a more northerly winter distribution. This pattern is clear from regional analysis of the data from the national midwinter counts (Nilsson \& Haas 2016) where a change to a more northerly distribution within the country was noted. At an international perspective, Lehikoinen et al. (2013) established a change in the winter distribution for the three diving ducks Common Goldeneye, Tufted Duck, and Common Merganser, which increased in the northern parts of their winter area and decreased in the southern parts. For further discussions of changes in distribution of diving ducks in relation to climate change, see also PavonJordan et al. (2015). 
Four species, Tufted Duck, Long-tailed Duck, Common Eider, and Common Merganser, showed significantly decreasing long-term trends for the study area on the south coast of Scania. On the contrary, both the Tufted Duck and the Common Merganser show significantly increasing long-term trends nationally (Nilsson \& Haas 2016, Haas \& Nilsson 2018). In both cases, regional analyses show clear changes in the winter distribution within the country to more northerly areas (Nilsson \& Haas 2016), as was also found at the international scale by Lehikoinen et al. (2013).

For the Long-tailed Duck and the Common Eider, the local trends for the south coast are just a reflection of geographically larger-scale declines noted in recent decades (Ekroos et al. 2012, Nilsson 2016). Since the 1990s, the Baltic population of Common Eider decreased markedly (Ekroos et al 2012). The national winter indices for the Common Eider show a long-term increase (Nilsson \& Haas 2016, Haas \& Nilsson 2018), but the much larger wintering population on the west coast of Sweden dominates these indices. The winter indices for the small wintering population of Common Eider in the Baltic Sea, of which the south coast area is a part, show a significantly decreasing trend in contrast to the west coast population (Haas \& Nilsson 2018).

The Long-tailed Duck is still the most common species in Swedish coastal waters, even if most of them stay offshore on the banks of the Baltic Sea (Nilsson 2016). During recent decades the wintering population in Swedish waters has decreased from about 1,400,000 in $1992 / 1993$ to about 400,000 or less in the last census in 2016 (Nilsson 2016). For the entire Baltic Sea a similarly large decrease occurred between the surveys in 1992/1993 and 2007-2009 (Skov et al. 2011; international estimates for 2016 not available yet).

The local decrease in the wintering numbers of Longtailed Ducks for the south coast of Scania was much more marked than any of the regional and local changes in the numbers noted for other wintering areas (Nilsson 2016). A few recent surveys of the offshore areas south of Scania have been undertaken (Nilsson 2016, Green \& Nilsson 2015), but there are no marked differences between these surveys and the old offshore surveys in the area (Nilsson 1972, 1980). The reasons for this difference are not known, but maybe the inshore waters are less optimal for the Long-tailed Duck than the offshore areas.

Some local changes in the distribution of the different wintering species were found when the different periods were compared. This was especially apparent for the dominant species, the Common Goldeneye. As noted above, the number of wintering Common Goldeneyes increased markedly during the study period. Meanwhile, there was a change in the distribution of the species with a higher proportion of wintering Common Goldeneyes found in the three western subareas. In fact, the number of Common Goldeneyes in the two eastern subareas did not show any clear changes over time. Maybe the most preferred areas with moraine coast in the two eastern subareas were already used more or less to capacity by the Common Goldeneyes in the early years, leading to an increase in the less preferred western subareas when yet more Common Goldeneyes overwintered in the area. During the intensive studies in the 1960 (Nilsson 1972) the sector between Hörte and Abbekås (in subarea 2) had a much higher use in the early part of the season than later and was clearly the most preferred subarea on the coast. This subarea did not show any clear changes in numbers over the years.

When it comes to the changes in distribution of the wintering waterbirds along the south coast of Scania and in other areas, local factors can of course be of some importance in addition to the large-scale climate factors discussed above. For the mussel-feeding diving ducks like the Tufted Duck, Long-tailed Duck, and the Common Eider, changes in the availability of food might be of importance. However, there are no data available for the study area regarding food resource levels. For the Common Eider and the Long-tailed Duck the trends are similar in the entire Baltic Sea. Everything points to climate changes as the main driver for species like the Tufted Duck and the Common Goldeneye. For species like the Mallard and the Eurasian Wigeon, they mostly use the coast as a roost making feeding flights inland at night, and are therefore not directly influenced by the marine environment.

\section{References}

Ekroos J, Fox AD, Christensen TK, Petersen IK, Kilpi M, Jonson JE, Green M, Laursen K, Cervenc A, de Boer P, Meissner W, Garthe S \& Öst M. 2012. Declines amongst breeding Eider Somateria mollissima numbers in the Baltic/Wadden Sea flyway. Ornis Fennica 89: 81-90.

Green M \& Nilsson L. 2015. The importance of offshore areas in southern Öresund, Sweden, for staging and wintering sea ducks. Ornis Svecica 25: 24-39. https://doi.org/10.34080/os.v25.21853 
Haas F \& Nilsson L. 2018. International counts of staging and wintering waterbirds and geese in Sweden. Annual report for 2017/2018. Department of Biology, Lund University, Lund. 50 pp. Available at http://tiny.cc/49kghz.

Lehikoinen A, Jaatinen K, Vähätalo AV, Clausen P, Crowe O, Deceuninck B, Hearn R, Holt CA, Hornman M, Keller V, Langedoen T, Nilsson L, Tomankova I, Wahl J \& Fox AD. 2013. Rapid climate driven shifts in wintering distributions of three common waterbird species. Global Change Biology 19: 2071-2081. https://doi.org/10.1111/gcb.1220o

Nilsson L. 1970a. Local and seasonal variation in sex-ratios of diving ducks in south Sweden during the non-breeding season. Ornis Scandinavica 1: 115-128. https://doi.org/10.2307/3676029

Nilsson L. 197ob. Food-seeking activity of south Swedish diving ducks during the non-breeding season. Oikos 21: 145-154. https://doi.org/10.2307/3543670

Nilsson L. 1970c. Non-breeding ecology of diving ducks in southernmost Sweden. PhD thesis, Lund University, Lund. $170 \mathrm{pp}$.

Nilsson, L. 1972. Habitat selection, food choice and feeding habits of diving ducks in coastal waters of south Sweden during the non-breeding season. Ornis Scandinavica 3: 55-78. https://doi. org/10.2307/3676166

Nilsson L. 1975. Inventeringar av rastande och övervintrande sjöfåglar i sydvästra Skåne 1961-1975. Anser 14: 93-108, 165-178, 225-236.

Nilsson L. 1980. De övervintrande alfåglarnas antal och utbredning längs den svenska kusten. Vår Fågelvärld 39: 1-14.
Nilsson, L. 2008. Changes in numbers and distribution of wintering waterfowl in Sweden during forty years, 1967-2006. Ornis Svecica 18: 135-226. https://doi.org/10.34080/os.v18.21852

Nilsson, L. 2016. Changes in numbers and distribution of wintering Long-tailed Ducks Clangula hyemalis in Swedish waters during the last fifty years. Ornis Svecica 26: 162-176. https://doi.org/10.34080/ os.v26.21855

Nilsson L \& Haas F. 2016. Distribution and numbers of wintering waterbirds in Sweden 2015 and changes during the last fifty years. Ornis Svecica 26: 3-54. https://doi.org/10.34080/os.v26.21854

Pavon-Jordan D, Fox AD, Clausen P, Dagys M, Deceuninck B, Devos K, Hearn RD, Holt CA, Hornman M, Keller V, Langedoen T, Lawickii L, Lorentsen SH, Luigujoe L, Meissner W, Musil P, Nilsson L, Paquet J-Y, Stipniece A, Stroud DA, Wahl J, Zenaqtello M \& Lehikoinen A. 2015. Climate-driven changes in winter abundance of a migratory waterbird in relation to EU protected areas. Diversity and Distributions 21: 571-582. https://doi.org/10.1111/ddi.12300

Skov H, Heinänen S, Žydelis R, Bellebaum J, Bzoma S, Dagys M, Durinck J, Garthe S, Grishanov G, Hario M, Kieckbusch JJ, Kube J, Kuresoo A, Larsson K, Luigujoe L, Meissner W, Nehls HW, Nilsson L, Petersen IK, Roos MM, Pihl S, Sonntag N, Stock A, Stipniece A \& Wahl J. 2011. Waterbird Populations and Pressures in the Baltic Sea. TemaNord 2011: 550 .

\section{Svensk sammanfattning}

Skånes sydkust har sedan lång tid varit känd som ett viktigt vinterområde för olika sjöfågelarter, inte minst under kalla isvintrar då området som regel kunnat erbjuda en del öppet vatten även under de kallaste perioderna.

Under åren 1964-1969 genomfördes intensiva undersökningar av de övervintrande dykänderna inom detta område, liksom i en del av Öresund (jfr Nilsson 1970a, 1970b, 1970c, 1972, 1975). I samband med dessa undersökningar startades regelbundna inventeringar av de övervintrande sjöfåglarna i området, vilka också ingår i de internationella midvinterinventeringarna av sjöfåglar (Nilsson 2008, Nilsson \& Haas 2016). I föreliggande uppsats analyserar jag de femtiofem årens midvinterinventeringar av sjöfåglar för att belysa förändringar i antalet för de olika arterna samt deras lokala utbredningsmönster.

\section{UNDERSÖKNINGSOMRÅDE OCH METODIK}

Inventeringsområdet omfattar den skånska sydkusten mellan Kämpinge och Ystad (figur 1) och består totalt av 20 räkningsenheter, vilka för de aktuella analyserna grupperats i fem delområden. De aktuella inventeringsenheterna har inventerats från lämpliga observationspunkter på stranden. För närmare beskrivning, se Nilsson (2008).

Generellt kännetecknas den skånska sydkusten av moränstränder, vilka skiljs åt av olika stora sandstränder. Exempel på moränstränder inom det viktigaste området mellan Hörte och Abbekås visas i figur 2. Två större hamnar finns i området, Trelleborg (som numera inte kan inventeras) och Ystad. Därutöver finns fyra mindre fiskehamnar.

Moränstränderna karakteriseras av omfattande tångbälten och ett rikt djurliv i vattnet med främst olika kräftdjur, företrädesvis av släktena Gammarus och Idothea. För detaljer om olika habitat och näringsförhållanden inom undersökningsområdet hänvisas till Nilsson (1972).

\section{RESULTAT OCH DISKUSSION}

Det totala antalet inräknade sjöfåglar vid de 55 årens 
midvinterinventeringar visade en betydande variation mellan olika år (figur 3). Som mest noterades runt 18000 övervintrare och som minst ungefär 2000 . Rent generellt visade totalantalet övervintrare en signifikant ökande trend över hela serien, vilken utgörs av ett ökat antal gräsänder Anas platyrhynchos.

Det övervintrande sjöfagelbeståndet dominerades av några få arter (figur 4) med knipan Bucephala clangula som den vanligaste arten med $35 \%$ av samtliga inräknade sjöfåglar under perioden. Därefter följde gräsanden, viggen Aythya fuligula och alfägeln Clangula hyemalis. Alfågeln utgjorde ett viktigt inslag i den övervintrande fågelfaunan under de första årens undersökningar, då upp till ett par tusen övervintrande alfåglar kunde räknas från stranden, medan arten endast sågs i låga tal under den senare delen av undersökningsperioden. Utöver de vanligaste arterna noterades tolv arter i mindre antal (tabell 1).

Antalet inräknade individer av de vanligaste av de olika arterna framgår av figur 5, medan de olika arternas fördelning på de fem delområdena under fyra tidsperioder illustreras i figur 6 . Några arter var starkt koncentrerade till vissa delar av undersökningsområdet såsom skäggdoppingen Podiceps cristatus, där större antal endast sågs öster om Abbekås. Några arter visade också ett förändrat fördelningsmönster under 55-årsperioden. Knipan visade en stark ökning totalt, men denna ökning var i princip begränsad till delområdena $3-5$, särskilt 3 , medan antalet övervintrande knipor i de östra delområdena 1-2 knappast visade någon ökning.

Signifikant ökande trender i antalet övervintrare längs den skånska sydkusten noterades för fyra arter: gräsand, knipa, sothöna Fulica atra och storskarv
Phalacrocorax carbo. Av dessa började storskarven först utnyttja sydkusten som vinterområde efter 1980 . Bläsanden Mareca penelope och skäggdoppingen tillhör också de arter som etablerade sig som en övervintrare i större antal i samband med de mildare vintrarna under senare år.

Fyra arter visade signifikant minskande lokala trender över undersökningsperioden: vigg, alfågel, ejder Somateria mollissima samt storskrake Mergus merganser. För vigg och storskrake visar nationella vinterindex ökande långtidstrender, varför den nedåtgående trenden för undersökningsområdet reflekterar en förskjutning av vinterutbredningen norrut i landet. Denna förskjutning norrut av vinterområdena förklarar också de ökande trenderna för bl. a. gräsand och knipa, där det skedde en förskjutning mot Sverige från områden längre söderut. Denna förskjutning norrut av vinterutbredningen har påvisats i de nationella inventeringarna för flera arter (Nilsson \& Haas 2016). På det internationella planet belyses detta för vigg, knipa och storskrake av Lehikoinen m. fl. (2013) samt för salskrake Mergellus albellus av Pavon-Jordan m. fl. (2015).

Alfågelns vinterbestånd i Östersjön har visat stora minskningar under senare år (Nilsson 2016, Skov m. fl. 2011). När det gäller ejdern visar hela Östersjöbeståndet en markant nedgång (Ekroos m. fl. 2012), däremot verkar västkustens ejdrar vara mer stabila. Nationella index för arten visar också ökande trender (Nilsson 2008, Nilsson \& Haas 2016), men på vintern förekommer mycket få övervintrande ejdrar i Östersjön, medan större antal övervintrar på den svenska västkusten. Långtidstrenden för västkusten är ökande, medan trenden för de fåtaligare Östersjö-ejdrarna varit starkt minskande (Haas \& Nilsson 2018).

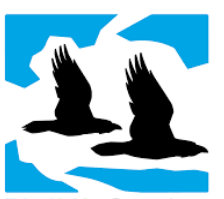

BirdLife Sverige

Ornis Svecica (ISSN 2003-2633) is an open access, peer-reviewed scientific journal published in English and Swedish by BirdLife Sweden. It covers all aspects of ornithology, and welcomes contributions from scientists as well as non-professional ornithologists. Accepted articles are published at no charge to the authors. Read papers or make a submission at os.birdlife.se.

Ornis Svecica (ISSN 2003-2633) är en fritt tillgänglig granskad vetenskaplig tidskrift som ges ut på svenska och engelska av BirdLife Sverige. Den täcker ornitologins alla områden och välkomnar bidrag från såväl forskare som icke-professionella ornitologer. Accepterade uppsatser publiceras utan kostnad för författarna. Läs uppsatser eller skicka in ditt bidrag på os.birdlife.se. 